ISSN 0258-7122 (Print), 2408-8293 (Online)

Bangladesh J. Agril. Res. 42(1): 171-184, March 2017

\title{
POSTHARVEST LOSS ASSESSMENT OF MAJOR FRUITS GROWN IN HILL REGIONS OF BANGLADESH
}

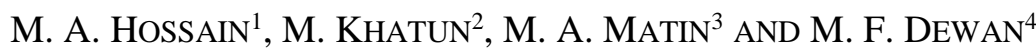

\begin{abstract}
The study was conducted for assessing postharvest loss of major fruits in different hill regions of Bangladesh. The study areas covered four hill districts, namely Rangamati, Khagrachari, Bandarban and Moulvibazar and six selected fruits, namely mango, jackfruit, litchi, banana, pineapple and orange. These fruits are grown intensively in hill regions compared to other parts of Bangladesh. Data were collected from 2050 fruit growers and 749 traders of eight (8) upazilas considering accessible and less accessible areas. At farmers and traders level, the total postharvest loss of banana, pineapple, orange, mango, litchi and jackfruit were 372, 274, 200, 243, 165 and $380 \mathrm{~kg} / \mathrm{mt}$ which was accounted about $37 \%, 27 \%, 20 \%, 24 \%, 17 \%$ and $38 \%$ of total production respectively. The main postharvest losses at farm level were incurred due to severe attack of insect, bat, squirrel and monkey. For traders, major losses were incurred during transportation. On the basis of retail price, the annual economic loss was estimated as Tk. 2107.5 crore and the maximum loss was incurred for banana (Tk. 705.79 crore) followed by pineapple (Tk. 550.58 crore) and mango (Tk. 508.95 crore) and the lowest for orange (Tk. 1.12 crore). It is interesting to note that, transportation dummy, labour dummy and market demand dummy had negative and significant effect on the postharvest losses. If transportation facilities can be improved and market demand and labour availability can be increased, postharvest loss will be decreased to an acceptable level at the study areas.
\end{abstract}

Keywords: Hill regions, fruits, postharvest loss, and national loss.

\section{Introduction}

The hilly areas have the great potentialities for fruit cultivation. Higher yield can be attained by adopting modern technologies as well as to mitigate balanced nutrition of the farmer. Most of the fruits like pineapple, mango, banana, jackfruit, guava, papaya, malta, orange, pomelo, litchi, lemon etc. are grown in different hilly areas of Bangladesh. The characteristics of agricultural commodities like fruits are bulky in production and perishable in nature. The surplus production of different fruits grown in hill regions are not marketed in proper time due to lack of transport and infrastructural facilities. Due to seasonal glut and absence of proper marketing system, bulk amount of harvested produce

${ }^{1 \& 3}$ Principal Scientific Officer, Agricultural Economics Division, Bangladesh Agricultural Research Institute (BARI), Gazipur, ${ }^{2}$ Scientific Officer, Agricultural Economics Division, BARI, Gazipur, ${ }^{4}$ Lecturer, Department of Economics and Poverty Study, Noakhali Science and Technology University, Noakhali, Bangladesh. 
get wasted every year. Postharvest losses occur at different points from fruit harvest to marketing chain. The extent of loss varies with the type of commodity and its level of management. In most of the developing countries, the postharvest loss is very high and it is about 50\% of fresh fruits and vegetable production. Even in developed countries like USA, Postharvest loss is up to $20 \%$ (Yahia and Oubahou, 2001). The postharvest loss of fruits and vegetables in Bangladesh ranged from $23.6 \%$ to $43.5 \%$ which accounts for an annual loss Tk. 3442 crore (Hassan, 2010). Similar losses of fruits and vegetables have also been reported from other Asia-Pacific countries, for example, $40 \%$ in India, 20-50\% in Indonesia, $20-50 \%$ in Korea, $27-42 \%$ in the Philippines, $16-41 \%$ in Srilanka, 17$35 \%$ in Thailand and $20-25 \%$ in Vietnam (Rolle, 2006). In general, the postharvest losses of fruits and vegetables in the developing countries are substantial (24-40\%) as compared to the developed countries (2-20\%) (Sirivatanapa, 2006).

The loss of any harvested crops has enormous negative impact on the economy of the country. By developing and adopting the appropriate techniques of postharvest technologies, a large amount of money can be saved annually which can make a significant contribution in case of food security of Bangladesh. Improved postharvest practices will bring financial gain to the farmers as well as satisfaction to the traders and consumers.

So, to compare with the previous studies an attempt had been made to analyse the present status of postharvest loss explaining the causes of postharvest loss both at farmers and traders level and also the factors responsible for this postharvest losses which will help in adopting appropriate interventions in reducing postharvest losses. Based on the postharvest losses, national economic loss as a whole was estimated on the basis of total production of the country for the year 2009-2010. Therefore, this study was undertaken with the following objectives:

i. To know the present status of postharvest losses of major fruits and their causes both at farmers and traders level;

ii. To find out the factors responsible for this postharvest losses;

iii. To estimate national economic loss per year.

\section{Methodology}

2.1 Study areas: The study areas covered four hill districts, namely Rangamati, Khagrachari, Bandarban and Moulavibazar where fruits are intensively grown compared to other parts of Bangladesh.

2.2 Sample size: From eight upazilas of four districts a total of 1230 growers were selected as sample farmers (Table 1). Another 820 farmers (Table 1) were selected whose gardens are more than 4 years old and presently they are 
marketed their fruits in the markets. In the case of different intermediaries, a total of 746 samples were selected from both primary and secondary markets of which 240 were local traders, 144 bepari, 48 urban aratdars, 144 local retailers and 96 were urban retailers.

Table 1. Distribution of fruits growing farmers according to different locations

\begin{tabular}{|c|c|c|c|c|c|c|c|c|c|}
\hline \multirow{3}{*}{$\begin{array}{l}\text { Name of } \\
\text { fruits }\end{array}$} & \multirow{3}{*}{$\begin{array}{c}\text { Total } \\
\text { sample } \\
(\mathrm{No})\end{array}$} & \multicolumn{8}{|c|}{ Farmers who are cultivating different fruits } \\
\hline & & \multicolumn{2}{|c|}{ Khagrachari } & \multicolumn{2}{|c|}{ Rangamati } & \multicolumn{2}{|c|}{ Bandarban } & \multicolumn{2}{|c|}{ Moulavibazar } \\
\hline & & Matiranga & Dighinala & Sadar & Naniarchar & Sadar & Ruma & Sreemongal & Juri \\
\hline Banana & 240 & 30 & 30 & 30 & 30 & 30 & 30 & 30 & 30 \\
\hline Pineapple & 210 & 30 & 30 & 30 & 30 & 30 & 30 & 30 & 0 \\
\hline Orange & 150 & 30 & 0 & 30 & 30 & 0 & 30 & 0 & 30 \\
\hline Mango & 180 & 30 & 30 & 30 & 30 & 30 & 30 & 0 & 0 \\
\hline Litchi & 210 & 30 & 30 & 30 & 30 & 30 & 0 & 30 & 30 \\
\hline Jackfruit & 240 & 30 & 30 & 30 & 30 & 30 & 30 & 30 & 30 \\
\hline Total & 1230 & 180 & 150 & 180 & 180 & 150 & 150 & 120 & 120 \\
\hline \multicolumn{10}{|c|}{ Farmers who are presently marketed their fruits } \\
\hline Farmer & 820 & 120 & 100 & 120 & 120 & 100 & 100 & 80 & 80 \\
\hline
\end{tabular}

2.3 Sampling technique: For selecting the farmers, simple random sampling technique and for intermediaries stratified proportionate random sampling technique for each group of intermediaries were followed. The farmers who possess more than 1 hectares of owned cultivable land and having the fruit garden (not less than 0.50 hectare) and depend on farming were selected as respondent farmers. The intermediaries werefaria, bepari, paiker, aratdar, wholesaler and retailer.

2.4 Postharvest loss assesment using multiple linear regression model: The data were collected from households on socioeconomic variables such as age, educational background, family members, occupation, earning person, average annual income. Information on different postharvest activities was collected from the respondents.Averages and percentages were used to compute the postharvest losses. Information about postharvest losses was obtained from the households during following operations: (i) harvesting, (ii) grading/handling (iii) loading/unloading and (iv) transportation. The total postharvest losses were estimated as a sum of all these losses. Functional analysis was carried out to examine the factors affecting postharvest losses at farm level in fruits, as used by Nag et al., (2000) in chickpea. The following multiple linear regression function was specified in the present study:

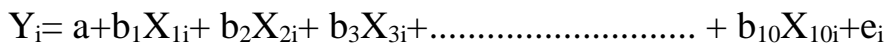


Where,

$Y_{i}=$ Postharvest losses of $i^{\text {th }}$ fruits at farm level in kg per ha.

$\mathrm{X}_{1 \mathrm{i}}=$ Age of the farmers in years.

$\mathrm{X}_{2 \mathrm{i}}=$ Education of the farmers in schooling years.

$\mathrm{X}_{3 \mathrm{i}}=$ Total production of $\mathrm{i}^{\text {th }}$ fruits in M.tons.

$\mathrm{X}_{4 \mathrm{i}}=$ Weather dummy which takes the value ' 1 ' if the weather during harvesting was favourable and value ' 0 ', otherwise.

$\mathrm{X}_{5 \mathrm{i}}=$ Transportation dummy which takes the value ' 1 ' if transport facility was adequate and value ' 0 ' otherwise.

$\mathrm{X}_{6 \mathrm{i}}=$ Labour dummy which takes the value ' 1 ' if the labour availability during harvesting was adequate and value ' 0 ' otherwise.

$\mathrm{X}_{7 \mathrm{i}}=$ Training dummy which takes the value ' 1 ' if the farmer received training about production and value ' 0 ' otherwise.

$\mathrm{X}_{8 \mathrm{i}}=$ Distance dummy which takes the value ' 1 ' if the distance from farm to market was favourable and value ' 0 ' otherwise.

$\mathrm{X}_{9 \mathrm{i}}=$ Market demand dummy which takes the value ' 1 ' if the market demand was favourable and value ' 0 ' otherwise.

$\mathrm{X}_{10 \mathrm{i}}=$ Market place dummy which takes the value ' 1 ' if the market place was favourable and value ' 0 ' otherwise

$\mathrm{a}=$ intercept.

$\mathrm{b}_{1}, \mathrm{~b}_{2}, \mathrm{~b}_{3,}, \ldots \ldots \ldots \ldots \ldots \mathrm{b}_{10}=$ Coefficients of the respective variable

$\mathrm{i}=1,2,3, \ldots 6$ and $1=$ banana, $2=$ pineapple, $3=$ orange, 4=mango, 5=litchi, $6=$ jackfruit.

$\mathrm{e}_{\mathrm{i}}=$ Random-error

\section{Results and Discussion}

\subsection{Postharvest loss at farmers' level}

Postharvest losses of different fruits at different operational stages at farm level in hilly areas are shown in Table 2 . For banana, the average loss per metric ton was $64 \mathrm{~kg}(6.4 \%)$ and highest loss $(1.4 \%)$ was occurred due to spoilage. Major portion of losses were found due to rough handling at harvesting $(1.3 \%)$ and insect attack (1.2\%). For pineapple, the amount of losses per metric ton was 66 $\mathrm{kg}(6.6 \%$ of total production) and the highest amount of losses was observed at harvesting (1.4\%) and spoilage loss (1.4\%). A notable portion (0.8\%) of 
pineapple was rotten due to rain. In the case of orange, average losses per metric ton was $94 \mathrm{~kg}$ (9.4\% of the total production). Farmers noted that highest loss $(2.6 \%)$ was occurred due to insect attack. Spoilage loss $(2.1 \%)$ was also prominent in orange. The total amount of losses for mango at farmers level was $98 \mathrm{~kg} / \mathrm{mt}$ which was $9.8 \%$ of total production. Major loss of mango is occurred due to insect attack (3\%), traditional harvesting system (1.7\%) and spoilage loss (1.5). Postharvest losses for litchi were $84 \mathrm{~kg} / \mathrm{mt}$ ( $8.4 \%$ of total production). Major portion of losses is occurred due to insect attack $(2.5 \%)$ and rough handling at harvesting stage $(1.5 \%)$. Besides, remarkable portion of losses is occurred at grading $(1 \%)$, storage $(0.9 \%)$ and spoilage loss $(1.3 \%)$.For jackfruit, per metric ton losses was $56 \mathrm{~kg}(5.6 \%)$ which is comparatively lower than other fruits and the highest amount of losses were observed due to insect attack (1.6\%). Losses of jackfruit also occurred due to storage $(0.6 \%)$, rough handling at harvesting $(1 \%)$, delay selling $(0.6 \%)$, grading $(0.4 \%)$ and spoilage $(0.5 \%)$.

For all fruits, the major postharvest loss occurred due to the attack of insect and pest at ripening stage (Table 2). Furthermore, a major portion of losses occured during harvesting and also due to spoilage during rainy season. This loss also occured due to lack of assembling point or temporary storage facilities for storage at market place.

Table 2. Postharvest losses of different fruits at farmers' level

\begin{tabular}{|c|c|c|c|c|c|c|}
\hline \multirow{2}{*}{ Particulars } & \multicolumn{6}{|c|}{ Fruits } \\
\hline & Banana & Pineapple & Orange & Mango & Litchi & Jackfruit \\
\hline Total yield (kg/ha) & 33653 & 21156 & 23622 & 22253 & 9243 & 32498 \\
\hline Total loss (kg/ha) & 2019(6) & $1481(7)$ & $2212(9)$ & $2151(10)$ & $774(8)$ & $1826(6)$ \\
\hline Loss (kg/mt) & $64(6.4)$ & $66(6.6)$ & $94(9.4)$ & $98(9.8)$ & $84(8.4)$ & $56(5.6)$ \\
\hline Harvesting loss (kg/mt) & $13(1.3)$ & $14(1.4)$ & $10(1)$ & $17(1.7)$ & $15(1.5)$ & $10(1)$ \\
\hline Grading loss (kg/mt) & $2(0.2)$ & $6(0.6)$ & $6(0.6)$ & $5(0.5)$ & $10(1)$ & $4(0.4)$ \\
\hline Storage loss (kg/mt) & $4(0.4)$ & $7(0.7)$ & $7(0.7)$ & $6(0.6)$ & $9(0.9)$ & $6(0.6)$ \\
\hline Delay selling (kg/mt) & $5(0.5)$ & $6(0.6)$ & $6(0.6)$ & $7(0.7)$ & $5(0.5)$ & $6(0.6)$ \\
\hline Weight loss (kg/mt) & - & $1(0.1)$ & $2(0.2)$ & $3(0.3)$ & - & - \\
\hline Spoilage loss (kg/mt) & $14(1.4)$ & $14(1.4)$ & $21(2.1)$ & $15(1.5)$ & $13(1.3)$ & $5(0.5)$ \\
\hline $\begin{array}{l}\text { Loss due to insect attack } \\
(\mathrm{kg} / \mathrm{mt})\end{array}$ & $12(1.2)$ & $6(0.6)$ & $26(2.6)$ & $30(3)$ & $25(2.5)$ & $16(1.6)$ \\
\hline $\begin{array}{l}\text { Rotten due to rain } \\
(\mathrm{Kg} / \mathrm{mt})\end{array}$ & $4(0.4)$ & $8(0.8)$ & $10(1)$ & $11(1.1)$ & $2(0.2)$ & $6(0.6)$ \\
\hline Other losses (Kg/mt) & $10(1)$ & $4(0.4)$ & $6(0.6)$ & $4(0.4)$ & $5(0.5)$ & $3(0.3)$ \\
\hline
\end{tabular}

Note: Figures in the parentheses indicate percentage of total losses

Others indicate fruits damage by monkey, bat and squirrel 
3.2 Postharvest losses at traders' level: The most important chain through which major amount of fruits (banana, orange, litchi and jackfruit) was transacted was Local trader-Bepari-Paikar-Urban retailer/Rural retailer-Consumer. For pineapple and mango the most important chain ofmarketingwas Local traderPaikar-Urban retailer-Rural retailerand Bepari-Paikar-Urban retailer, respectively. For all fruits except mango, postharvest losses were found more in urban retailer level than other traders. The main reason for losses in urban retailer level was due to the poor storage facilities and delay selling of the product. Sometimes it required more time to dispose of due to large supply of the same product in the market.In case of mango the highest losses occured in case of Bepari followed by urban retailer. The major cause of postharvest losses for all traders were found to be due to carrying/transportation followed by delay selling and storage loss.

\section{Postharvest losses of banana at traders' level}

As banana is a highly perishable product and it stays comparatively more time to the traders,postharvest losses at intermediaries' level were much higher than farm level. Highest losses of banana were found in case of urban retailers (8.9\%) and comparatively lower losses were found in case of rural retailers $(3.2 \%)$. Total $30.8 \%$ losses were found at traders' level (Table 3). Highest $8.8 \%$ loss was occurred in case of carrying banana from one area to another. This is because of having poor road and transportation facilities in the hill areas. In Ethiopia Mebratie et.al (2015) estimated postharvest losses as higher at retailers level (56\% of total loss) while the wholesale and farm levels' losses were $27 \%$ and $17 \%$, respectively.

Table 3. Postharvest losses of banana at different intermediaries level $(\mathrm{kg} / \mathrm{mt})$

\begin{tabular}{l|c|c|c|c|c|c}
\hline \multicolumn{1}{c|}{ Particulars } & $\begin{array}{c}\text { Local } \\
\text { Trader }\end{array}$ & Bepari & Paiker & $\begin{array}{c}\text { Urban } \\
\text { Retailer }\end{array}$ & $\begin{array}{c}\text { Rural } \\
\text { Retailer }\end{array}$ & Total loss \\
\hline Loading/Unloading & $5(0.5)$ & $8(0.8)$ & $9(0.9)$ & $6(0.6)$ & $7(0.7)$ & $35(3.5)$ \\
Carrying & $12(1.2)$ & $38(3.8)$ & $21(2.1)$ & $9(0.9)$ & $8(0.8)$ & $88(8.8)$ \\
Grading \& Packing & $8(0.8)$ & $6(0.6)$ & $6(0.6)$ & - & $5(0.5)$ & $25(2.5)$ \\
Storage loss & $20(2)$ & $5(0.5)$ & $6(0.6)$ & $29(2.9)$ & $6(0.6)$ & $66(6.6)$ \\
Delay Selling & $20(2)$ & $6(0.6)$ & $4(0.4)$ & $30(3)$ & $3(0.3)$ & $63(6.3)$ \\
Spoilage loss & $7(0.7)$ & $4(0.4)$ & $2(0.2)$ & $15(1.5)$ & $3(0.3)$ & $31(3.1)$ \\
Total loss & $72(7.2)$ & $67(6.7)$ & $48(4.8)$ & $89(8.9)$ & $32(3.2)$ & $308(30.8)$ \\
\hline
\end{tabular}

Note: Figures in the parentheses indicate losses in percentage

\section{Postharvest losses of pineapple at traders' level}

Postharvest losses of pineapple at intermediaries' level were much higher than farm level. Total losses at traders' level were found $20.8 \%$. Highest losses of 
pineapple were found in case of urban retailers (9.6\%) and comparatively lower losses were found in case of rural retailers $(2.5 \%)$. (Table 4). Highest (5\%) losses were occurred in case of carrying pineapple from one area to another. This is because of having poor road and transportation facilities in the hill areas. A noticeable portion of pineapple was lost due to delay selling (4.6\%).

Table 4. Postharvest losses of pineapple at different intermediaries' level $(\mathrm{kg} / \mathrm{mt})$

\begin{tabular}{lcc|c|c|c|c}
\hline Particulars & Local trader & Paiker & Urban retailer & Rural retailer & Total \\
\hline Loading/Unloading & $10(1)$ & $8(0.8)$ & $9(0.9)$ & $6(0.6)$ & $33(3.3)$ \\
Carrying & $18(1.8)$ & $12(1.2)$ & $14(1.4)$ & $6(0.6)$ & $50(5)$ \\
Grading \& Packing & $8(0.8)$ & $5(0.5)$ & $8(0.8)$ & $5(0.5)$ & $26(2.6)$ \\
Storage loss & $10(1)$ & $6(0.6)$ & $26(2.6)$ & $2(0.2)$ & $44(4.4)$ \\
Delay Selling & $3(0.3)$ & $7(0.7)$ & $30(3)$ & $6(0.6)$ & $46(4.6)$ \\
Spoilage loss & - & - & $9(0.9)$ & - & $9(0.9)$ \\
Total loss & $49(4.9)$ & $38(3.8)$ & $96(9.6)$ & $25(2.5)$ & $208(20.8)$ \\
\hline
\end{tabular}

Note: Figures in the parentheses indicate losses in percentage

\section{Postharvest losses of orange at traders' level}

Postharvest losses of orange at intermediaries' and farm level were more or lesssimilar. Total losses at traders' level were found $10.7 \%$. Highest losses were found in case of urban retailers $(5.4 \%)$ and comparatively lower losses were found in case of local traders $(0.6 \%)$ (Table 5). Highest $(2.6 \%)$ losses were occurred in case of carrying one area to another. This is because of having poor road and transportation facilities in the hill areas. A noticeable portion of losses were found due to delay selling $(2.1 \%)$ and spoilage losses $(2.1 \%)$.

Table 5. Postharvest losses of orange at different intermediaries' level (kg/mt)

\begin{tabular}{l|c|c|c|c|c|c}
\hline \multicolumn{1}{c|}{ Particulars } & $\begin{array}{c}\text { Local } \\
\text { trader }\end{array}$ & Bepari & Paiker & $\begin{array}{c}\text { Urban } \\
\text { retailer }\end{array}$ & $\begin{array}{c}\text { Rural } \\
\text { retailer }\end{array}$ & Total \\
\hline Loading/Unloading & $2(0.2)$ & $3(0.3)$ & $2(0.2)$ & $8(0.8)$ & $3(0.3)$ & $18(1.8)$ \\
Carrying & $2(0.2)$ & $7(0.7)$ & $5(0.5)$ & $8(0.8)$ & $5(0.5)$ & $26(2.6)$ \\
Grading \& Packing & $1(0.1)$ & $2(0.2)$ & $1(0.1)$ & $3(0.3)$ & - & $7(0.7)$ \\
Storage loss & $1(0.1)$ & $3(0.3)$ & $1(0.1)$ & $12(1.2)$ & $4(0.4)$ & $21(2.1)$ \\
Delay Selling & - & $4(0.4)$ & - & $15(1.5)$ & $4(0.4)$ & $21(2.1)$ \\
Spoilage loss & - & $2(0.2)$ & - & $10(1)$ & $1(0.1)$ & $14(1.4)$ \\
Total loss & $6(0.6)$ & $21(2.1)$ & $9(0.9)$ & $54(5.4)$ & $17(1.7)$ & $107(10.7)$ \\
\hline
\end{tabular}

Note: Figure in the parentheses indicate losses in percentage.

\section{Postharvest losses of mango at traders' level}

Postharvest losses of mango at intermediaries' level were found $14.5 \%$ which was higher than farm level. Highest losses of mango were found in case of 
beparilevel (7.2\%) which was about half of the total losses at traders' level and comparatively lower losses were found in case of paikers level (1.9\%) (Table 6). Highest $(5.5 \%)$ losses were occurred in case of carrying mango from one area to another. Poor road and transportation facilities in the hilly areas are the major causes of losses at traders level. A noticeable portion of mango was lost due to storing mango at traders' level $(2.6 \%)$.

Table 6. Postharvest losses of mango at different intermediaries' level (kg/mt)

\begin{tabular}{lccccc}
\hline \multicolumn{1}{c|}{ Particulars } & Bepari & Paiker & Urbanretailer & Total \\
\hline Loading/Unloading & $14(1.4)$ & $5(0.5)$ & $3(0.3)$ & $22(2.2)$ \\
Carrying & $40(4)$ & $8(0.8)$ & $7(0.7)$ & $55(5.5)$ \\
Grading \& Packing & $4(0.4)$ & $3(0.3)$ & - & $7(0.7)$ \\
Storage loss & $9(0.9)$ & $3(0.3)$ & $14(1.4)$ & $26(2.6)$ \\
Delay Selling & $5(0.5)$ & - & $17(1.7)$ & $22(2.2)$ \\
Spoilage loss & - & - & $13(1.3)$ & $13(1.3)$ \\
Total loss & $72(7.2)$ & $19(1.9)$ & $54(5.4)$ & $145(14.5)$ \\
\hline
\end{tabular}

Note: Figure in the parentheses indicate losses in percentage

\section{Postharvest losses of Litchi at traders' level}

Postharvest losses of litchi at intermediaries' level were $8.1 \%$ which is similar to farm level (Table 7). The perishability of this fruit is attributed to immense physiological changes after harvest (Momen et. al., 1993). Amiruzzaman (1990) reported that postharvest losses of fresh fruits including litchi in Bangladesh is $25-50 \%$, while it is only $5-25 \%$ in developed countries (Khader, 1992). Highest losses of litchi were found in case of urban retailer (4.3\%) and comparatively lower loss was found in case of bepari (0.9\%) (Table 7). Molla et. al. (2010) reported that average losses of litchi at growers, beparies, arathdars, retailers, and and consumers level were found as $13 \%, 4.25 \%, 7.75 \%, 4.10 \%$, and $7.50 \%$ respectively. Highest $(2.6 \%)$ losses were occurred in case of carrying litchi from one area to another. This is because of having poor road and transportation facilities in the hill areas. A noticeable portion of litchi was lost in the time of grading and packing $(1.9 \%)$.

Table 7. Postharvest losses of Litchi at different intermediaries' level (kg/mt)

\begin{tabular}{l|c|c|c|c|c|c}
\hline \multicolumn{1}{c}{ Particulars } & Localtrader & Bepari & Paiker & Urbanretailer & Ruralretailer & Total \\
\hline Loading/Unloading & - & $2(0.2)$ & $4(0.4)$ & $8(0.8)$ & $4(0.4)$ & $18(1.8)$ \\
Carrying & $1(0.1)$ & $3(0.3)$ & $3(0.3)$ & $12(1.2)$ & $7(0.7)$ & $26(2.6)$ \\
Grading \& Packing & - & $4(0.4)$ & $2(0.2)$ & $9(0.9)$ & $4(0.4)$ & $19(1.9)$ \\
Storage loss & - & - & $2(0.2)$ & - & - & $2(0.2)$ \\
Delay Selling & - & - & - & $8(0.8)$ & $2(0.2)$ & $10(1)$ \\
Spoilage loss & - & - & - & $6(0.6)$ & - & $6(0.6)$ \\
Total loss & $1(0.1)$ & $9(0.9)$ & $11(1.1)$ & $43(4.3)$ & $17(1.7)$ & $81(8.1)$ \\
\hline
\end{tabular}

Note: Figures in the parentheses indicate losses in percentage 


\section{Postharvest losses of jackfruit at traders' level}

Postharvest losses of jackfruit at intermediaries' level were much higher than farm level. Total losses at traders' level were found $32.4 \%$. Highest losses of jackfruit were found in case of bepari and urban retailers $(9.5 \%)$ and comparatively lower losses were found in case of rural retailers $(2.3 \%)$. (Table $8)$. Highest $(15.1 \%)$ losses were occurred in case of carrying jackfruit from one area to other. This is because of having poor road and transportation facilities in the hill areas. A noticeable portion of jackfruit was lost in the time of loading/unloading and storing at traders' level (6.2\%).

Table 8. Postharvest losses of Jackfruit at different intermediaries' level (kg/mt)

\begin{tabular}{l|c|c|c|c|c|c}
\hline \multicolumn{1}{c|}{ Particulars } & Localtrader & Bepari & Paiker & Urbanretailer & Ruralretailer & Total \\
\hline Loading/Unloading & $12(1.2)$ & $18(1.8)$ & $16(1.6)$ & $13(1.3)$ & $2(0.2)$ & $62(6.2)$ \\
Carrying & $25(2.5)$ & $45(4.5)$ & $32(3.2)$ & $43(4.3)$ & $7(0.7)$ & $151(15.1)$ \\
Grading \& Packing & $5(0.5)$ & $10(1)$ & $9(0.9)$ & - & - & $23(2.3)$ \\
Storage loss & $6(0.6)$ & $13(1.3)$ & $6(0.6)$ & $25(2.5)$ & $9(0.9)$ & $62(6.2)$ \\
Delay Selling & - & $9(0.9)$ & - & $10(1)$ & $5(0.5)$ & $23(2.3)$ \\
Spoilage loss & - & - & - & $4(0.4)$ & - & $3(0.3)$ \\
Total loss & $48(4.8)$ & $95(9.5)$ & $63(6.3)$ & $95(9.5)$ & $23(2.3)$ & $324(32.4)$ \\
\hline
\end{tabular}

Note: Figures in the parentheses indicate losses in percentage

\subsection{Total Postharvest losses}

The postharvest losses of banana, pineapple, orange, mango, litchi and jackfruit at traders level were worked out as $308 \mathrm{~kg}, 208 \mathrm{~kg}, 106 \mathrm{~kg}, 145 \mathrm{~kg}, 81 \mathrm{~kg}$ and $324 \mathrm{~kg}$ per ton respectively (Table 9). The total loss that represent about $30.8 \%$, $20.88 \%, 10.6 \%, 14.5 \%, 8.1 \%$ and $32.4 \%$ of total volume of fruits handled by different intermediaries. Total post- harvest losses of banana, pineapple, orange, mango, litchi and jackfruit were found $37 \%, 27 \%, 20 \%, 24 \%, 17 \%$, and $38 \%$, respectively.

Table 9. Postharvest losses at farmers and traders level $(\mathrm{kg} / \mathrm{mt})$

\begin{tabular}{ccccc}
\hline Fruits & Farmers loss $(\mathrm{kg} / \mathrm{mt})$ & Traders loss $(\mathrm{kg} / \mathrm{mt})$ & Total loss $(\mathrm{kg} / \mathrm{mt})$ \\
\hline Banana & $64(6.4)$ & $308(30.8)$ & $372(37)$ \\
Pineapple & $66(6.6)$ & $208(20.8)$ & $274(27)$ \\
Orange & $94(9.4)$ & $106(10.6)$ & $200(20)$ \\
Mango & $98(9.8)$ & $145(14.5)$ & $243(24)$ \\
Litchi & $84(8.4)$ & $81(8.1)$ & $165(17)$ \\
Jackfruit & $56(5.6)$ & $324(32.4)$ & $380(38)$ \\
All Average & $77(7.7)$ & $195(19.5)$ & $272(27.2)$ \\
\hline
\end{tabular}

Note: Figures in the parentheses indicate losses in percentage 


\subsection{National economic loss assessment}

Both at farmers and traders level, the total postharvest lossesfor banana, pineapple,orange ,mango, litchi, and jackfruit were 372, 274, 200, 243, 165, and $380 \mathrm{~kg} / \mathrm{mt}$ (Table 10). The total economic loss of major fruits was calculated on the basis of the latest production data obtained from BBS 2010. Based on harvest price,national economic loss was estimated to be Tk. 922.17 crore. The maximum loss was incurred for mango (Tk. 364.12 crore) and the lowest for orange (Tk. 0.37 crore). Similarly, on the basis of retail price, the total economic loss was estimated to be Tk. 2341.66crore and the maximum loss was incurred for banana(Tk. 705.79 crore) followed by pineapple (Tk. 550.58 crore) and mango (Tk. 508.95 crore) and the lowest for orange (Tk. 1.12 crore). In monetary term, the prices prevailing in retail market is always higher than the farm harvest price. So in retail level, the postharvest losses were highest. Actual economic loss was again estimated considering $10 \%$ acceptable loss both at farmers and traders level. By considering 10\% acceptable loss, the total postharvest losses were estimated Tk. 829.95 crore/year at farm harvest price and Tk. 2107.50 crore/year at retail price.

Table 10. Annual economic loss of fruits occurred at harvest and postharvest stages

\begin{tabular}{lcc|c|c|c|c|c}
\hline Particulars & Banana & Pineapple & Orange & Mango & Litchi & Jackfruit & Total \\
\hline $\begin{array}{l}\text { Production (mt) } \\
\text { Loss at }\end{array}$ & 818254 & 234493 & 2666 & 1047849 & 64995 & 1005164 & 4173421 \\
farmers\&traders level & 372 & 274 & 200 & 243 & 165 & 380 & 1634 \\
$\begin{array}{l}\text { in study areas (kg/mt) } \\
\text { Total national loss (mt) }\end{array}$ & 304390 & 64251 & 533 & 254627 & 10724 & 381962 & 1016487 \\
$\begin{array}{l}\text { Harvest price (Tk./mt) } \\
\text { Retail price (Tk./mt) }\end{array}$ & 6017 & 25809 & 6920 & 14300 & 88542 & 2978 & \\
$\begin{array}{l}\text { Total loss based on } \\
\text { harvest price (crore Tk.) }\end{array}$ & 183.15 & 165.83 & 0.37 & 364.12 & 94.95 & 113.75 & 922.17 \\
$\begin{array}{l}\text { Total loss based on } \\
\text { retail price (crore Tk.) }\end{array}$ & 705.79 & 550.58 & 1.12 & 508.95 & 193.26 & 381.96 & 2341.66 \\
\hline
\end{tabular}

\subsection{Factors affecting postharvest losses at farm level}

For studying the influence of different socio-economic features of farmers on postharvest losses at the farm level, a multiple linear regression analysis was carried out. The estimated regression coefficients are presented in table 11 to table 13. The variations in 10 independent variables included in the regression model explained nearly 59per cent in the total postharvest losses in banana, 68 per cent in pineapple, 59 per cent in orange, 79 per cent in mango, 75 per cent in 
litchi and 69 per cent in jackfruit. The F-ratio was significant in all cases, indicating thereby the good fit of the regression models.

Table 11. Estimated values of coefficients and related statistics of multiple linear regression model for postharvest losses of banana and pineapple at farmers' level

\begin{tabular}{|c|c|c|c|c|}
\hline \multirow{2}{*}{ Explanatory variables } & \multicolumn{2}{|c|}{ Banana } & \multicolumn{2}{|c|}{ Pineapple } \\
\hline & Coefficients & P-value & Coefficients & $\mathrm{P}$-value \\
\hline Intercept & $10.034^{* *}$ & 0.052 & $12.071^{* *}$ & 0.053 \\
\hline Age of the farmer(years) $X_{1}$ & 0.039 & 0.193 & 6.722 & 0.539 \\
\hline Education (Schooling years) $\mathrm{X}_{2}$ & 0.432 & 0.372 & 0.790 & 0.695 \\
\hline Total production (M.ton) $\mathrm{X}_{3}$ & 0.820 & 0.489 & $10.005^{*}$ & 0.065 \\
\hline Weather dummy $\mathrm{X}_{4}$ & 1.029 & 0.702 & $-0.192^{* *}$ & 0.053 \\
\hline Transportation dummy $\mathrm{X}_{5}$ & $-0.043^{* * *}$ & 0.002 & $-0.034^{* *}$ & 0.040 \\
\hline Labour dummy $\mathrm{X}_{6}$ & 0.925 & 0.429 & $-1.294^{* * *}$ & 0.000 \\
\hline Training dummy $\mathrm{X}_{7}$ & 1.043 & 0.792 & 0.009 & 0.649 \\
\hline Distance dummy $\mathrm{X}_{8}$ & $-1.503^{* *}$ & 0.040 & $-1.002^{* *}$ & 0.024 \\
\hline Market demand dummy $\mathrm{X}_{9}$ & $-0.294^{*}$ & 0.063 & $-0.139^{* * *}$ & 0.001 \\
\hline Market place dummy $\mathrm{X}_{10}$ & 0.043 & 0.673 & 0.943 & 0.709 \\
\hline $\mathrm{N}$ & \multicolumn{2}{|c|}{90} & \multicolumn{2}{|l|}{120} \\
\hline $\mathrm{R}^{2}$ & \multicolumn{2}{|c|}{0.592} & \multicolumn{2}{|c|}{0.682} \\
\hline $\mathrm{F}$ value & \multicolumn{2}{|c|}{$17.850^{* * *}$} & \multicolumn{2}{|c|}{$27.042^{* *}$} \\
\hline
\end{tabular}

It is clear that in case of banana (Table 11) and litchi (Table 13), the variables like transportation dummy, distance dummy and market demand dummy were negatively significant which indicate that with the increase of transportation facilities and market demand, postharvest loss will decrease. Again, if the distance from farm to market is favourable to the farmer, postharvest loss will also decrease.

In case of pineapple (Table11) the variables like weather dummy, transportation dummy, labour dummy, distance dummy and market demand dummy were negatively significant which indicate that with the increase of transportation facilities, labour availabilities and market demand, postharvest loss will decrease. If the weather and distance from farm to market is favourable to the farmer, postharvest loss will decrease. Total production had positive and significant relationship with total postharvest losses which indicates that, with the increase of production of pineapple, postharvest loss will increase. 
Table 12. Estimated values of coefficients and related statistics of multiple linear regression model for postharvest losses of orange and mango at farmers level

\begin{tabular}{|c|c|c|c|c|}
\hline \multirow{2}{*}{ Explanatory variables } & \multicolumn{2}{|c|}{ Orange } & \multicolumn{2}{|c|}{ Mango } \\
\hline & Coefficients & P-value & Coefficients & P-value \\
\hline Intercept & $-6.750^{* * *}$ & 0.000 & $0.642^{* *}$ & 0.023 \\
\hline Age of the farmer (years) $X_{1}$ & 1.250 & 0.430 & 0.239 & 0.234 \\
\hline Education (Schooling years) $\mathrm{X}_{2}$ & 0.893 & 0.690 & 0.094 & 0.109 \\
\hline Total production (M.ton) $\mathrm{X}_{3}$ & $7.843^{*}$ & 0.070 & $8.034^{* *}$ & 0.042 \\
\hline Weather dummy $\mathrm{X}_{4}$ & -2.095 & 1.007 & 1.027 & 0.639 \\
\hline Transportation dummy $\mathrm{X}_{5}$ & $-0.043^{* *}$ & 0.045 & $-0.039^{* * * *}$ & 0.003 \\
\hline Labour dummy $\mathrm{X}_{6}$ & $-0.375^{* *}$ & 0.050 & $-0.005^{*}$ & 0.067 \\
\hline Training dummy $\mathrm{X}_{7}$ & 0.008 & 0.200 & 1.752 & 0.920 \\
\hline Distance dummy $\mathrm{X}_{8}$ & 0.002 & 0.870 & -0.829 & 0.439 \\
\hline Market demand dummy $\mathrm{X}_{9}$ & $-1.039^{* * *}$ & 0.005 & $-0.052^{* *}$ & 0.042 \\
\hline Market place dummy $\mathrm{X}_{10}$ & 0.007 & 1.002 & 2.701 & 0.597 \\
\hline $\mathrm{N}$ & \multicolumn{2}{|c|}{90} & \multicolumn{2}{|c|}{180} \\
\hline $\mathrm{R}^{2}$ & \multicolumn{2}{|c|}{0.592} & \multicolumn{2}{|c|}{0.790} \\
\hline $\mathrm{F}$ value & \multicolumn{2}{|c|}{$17.850^{* *}$} & \multicolumn{2}{|c|}{$20.430^{* *}$} \\
\hline
\end{tabular}

‘**', '**' and ${ }^{(*)}$ denote $1 \%, 5 \%$ and $10 \%$ level of significance

In case of orange and mango (Table 12) and jackfruit (Table 13), the variables like transportation dummy, labour dummy and market demand dummy were negatively significant which indicate that with the increase of transportation facilities, labour availabilities and market demand, postharvest loss will decrease. Total production had positive and significant relationship with total postharvest losses which indicates that, with the increase of production of fruits like mango, orange and jackfruit, postharvest loss will increase.

It is interesting to note that, transportation dummy and market demand dummy were negatively significant for all fruits in all locations. If these facilities like transportation, market demand and labour availability can be increased, postharvest loss will decrease at the study areas. Scarcity in storage and transportation infrastructure resulted in $25-40$ percent postharvest losses that shrinks supply and put pressure on prices. 
Table13. Estimated values of coefficients and related statistics of multiple linear regression model for postharvest losses of litchi and jackfruit at farmers' level.

\begin{tabular}{|c|c|c|c|c|}
\hline \multirow{2}{*}{ Explanatory variables } & \multicolumn{2}{|c|}{ Litchi } & \multicolumn{2}{|c|}{ Jackfruit } \\
\hline & Coefficients & P-value & Coefficients & P-value \\
\hline Intercept & $15.228^{* * *}$ & 0.001 & $3.019^{* *}$ & 0.053 \\
\hline Age of the farmer (years) $X_{1}$ & -0.780 & 0.901 & 0.872 & 0.672 \\
\hline Education (Schooling years) $\mathrm{X}_{2}$ & 0.815 & 0.875 & -0.734 & 0.220 \\
\hline Total production (M. ton) $\mathrm{X}_{3}$ & 0.058 & 0.632 & 9.073 & 0.782 \\
\hline Weather dummy $\mathrm{X}_{4}$ & -0.728 & 0.557 & 1.792 & 0.900 \\
\hline Transportation dummy $\mathrm{X}_{5}$ & $-0.5433^{* *}$ & 0.053 & $-0.472^{* * *}$ & 0.001 \\
\hline Labour dummy $\mathrm{X}_{6}$ & 0.039 & 0.542 & $-0.927^{*}$ & 0.067 \\
\hline Training dummy $\mathrm{X}_{7}$ & 0.495 & 0.352 & 0.027 & 0.697 \\
\hline Distance dummy $\mathrm{X}_{8}$ & $-0.870^{* *}$ & 0.030 & 0.407 & 0.824 \\
\hline Market demand dummy $\mathrm{X}_{9}$ & $-0.156 *$ & 0.073 & $-0.039 * *$ & 0.043 \\
\hline Market place dummy $\mathrm{X}_{10}$ & 0.782 & 0.791 & 0.053 & 0.789 \\
\hline $\mathrm{N}$ & \multicolumn{2}{|c|}{210} & \multicolumn{2}{|c|}{210} \\
\hline $\mathrm{R}^{2}$ & \multicolumn{2}{|c|}{0.751} & \multicolumn{2}{|c|}{0.692} \\
\hline F value & \multicolumn{2}{|c|}{$22.032^{* * *}$} & \multicolumn{2}{|c|}{$32.029^{* *}$} \\
\hline
\end{tabular}

‘**, '**' and '*' denote $1 \%, 5 \%$ and $10 \%$ level of significance

\section{Summary}

At farmers and traders level, the total postharvest loss of banana, pineapple, orange, mango, litchi and jackfruit were $372,274,200,243,165$, and $380 \mathrm{~kg} / \mathrm{mt}$ which was accounted about $37 \%, 27 \%, 20 \%, 24 \%, 17 \%$ and $38 \%$ of total yield respectively. The main Postharvest losses were incurred due to severe attack of insect and severe attack of bat, squirrel and monkey for farmers. For traders, major loss was incurred during transportation. On the basis of retail price, the total economic loss was estimated as Tk. 2341.66 crore and the maximum loss was incurred for banana (Tk. 705.79 crore) followed by pineapple (Tk. 550.58 crore) and mango (Tk. 508.95 crore) and the lowest for orange (Tk. 1.12 crore). It is interesting to note that, transportation dummy and market demand dummy were negatively significant for all fruits in all locations. If these facilities like transportation, market demand and labour availability can be increased, postharvest loss will be decreased to an acceptable level at the study areas. Lack of technical knowledge about Postharvest activities, severe attacks of insect and pest, attacks by bat, squirrel, monkey, storage facilities, transportation facilities, lack of agro processing industries and low prices were identified as the major constraints in the hill areas of Bangladesh. 


\section{Recommendations}

The following policies/suggestions should be implemented which deserves immediate attention for reducing the existing postharvest loss of major fruits in hill regions of Bangladesh:

- An appropriate training programme on different postharvest activities like handling, grading, packaging, carrying etc. should be provided with a view to increasing the efficiency as well as awareness of the farmers and traders.

* Storage facilities should be established in hilly areas to ensure fair price of their product. Private entrepreneur should come forward to establish storage facilities at the important fruit concentrated areas and different wholesale and retail markets. Facilities should be developed for one to two days reservation for unsold fruits at market place.

* Transportation and communication system should be developed through constructing of different feeder road. Low cost quick transportation facilities will ensure to carry fruits from farmyard to local market place or in distant bigger market for the farmers and intermediaries where they are likely to get better price for their products.

\section{References}

Amiruzzaman, M. 1990. Postharvest handling and processing of fruits and vegetables. In: Kitchen Gardening and Homestead Productive Activities. CIRDAP Action Research. Series no. 11. P. 22

Hassan, M. K.. 2010. Final Report- Postharvest Loss Assessment: A Study to Formulate Policy for Loss Reduction of Fruits and Vegetables and Socio-Economic Uplift of the Stake holders (Funded by USAID and EC \& Jointly implemented by FAO and FPMU of MoFDM), p. 189.

Khader, A. A. 1992. Postharvest Technology of Horticultural Crops. $2^{\text {nd }}$ ed. Univ. of California. Divn. of Agric and Natural Resources. Publication No. 3311.

Molla, M. M., M. N. Islam, T. A. A. Nasrin and M. A. J. Bhuyan. 2010. Survey on Postharvest Practices and Lossess of Litchi in selected Areas of Bangladesh. Bangladesh J. Agril. Res. 35 (3): 439-451.

Momen, M. N., M. A. Rahim, A. M. Farooque and M. S. H. Choudhury. 1993. Effect of some coating materials and physical measures on the prolongation of shelf life of banana. Agric. 4 (1-2): 41-51.

Rolle, R. S. 2006. Improving postharvest management and marketing in the Asia-Pacific regions: Postharvest Management of Fruits and Vegetables in Asia-Pacific Region, FAO (Food and Agricultural Organizations) and APO (Asian Productivity Organization), Pp. 23-31.

Sirivatanapa, S. 2006. Packaging and transportation of fruits and vegetables for better marketing: Postharvest Management of Fruits and Vegetables in Asia-Pacific Region. FAO (Food and Agricultural Organization) and APO (Asian Productivity Organization). Pp. 43-48.

Yahia, E. M. and A. Oubahou. 2001. Postharvest Physiology: Technology and Handling of Horticultural Crops, Winrock International Institute of Agricultural Development, p.139. 